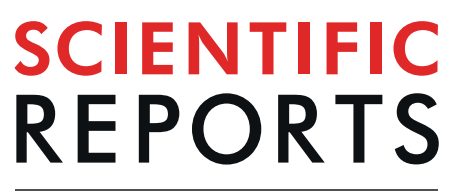

natureresearch

\title{
OPEN
}

Published online: 17 January 2020

\section{Author Correction: Definitive evidence of the presence of 24-methylenecycloartanyl ferulate and 24-methylenecycloartanyl caffeate in barley}

\author{
Junya Ito, Kazue Sawada, Yusuke Ogura, Fan Xinyi, Halida Rahmania, Tomoyo Mohri, \\ Noriko Kohyama, Eunsang Kwon, Takahiro Eitsuka, Hiroyuki Hashimoto, \\ Shigefumi Kuwahara, Teruo Miyazawa \& Kiyotaka Nakagawa
}

Correction to: Scientific Reports https://doi.org/10.1038/s41598-019-48985-6, published online 29 August 2019

In the Supplementary Information file originally published with this Article, the dataset 'Supplementary Information 4' was omitted. This error has been corrected in the Supplementary Information file that now accompanies the Article.

(c) (i) Open Access This article is licensed under a Creative Commons Attribution 4.0 International License, which permits use, sharing, adaptation, distribution and reproduction in any medium or format, as long as you give appropriate credit to the original author(s) and the source, provide a link to the Creative Commons license, and indicate if changes were made. The images or other third party material in this article are included in the article's Creative Commons license, unless indicated otherwise in a credit line to the material. If material is not included in the article's Creative Commons license and your intended use is not permitted by statutory regulation or exceeds the permitted use, you will need to obtain permission directly from the copyright holder. To view a copy of this license, visit http://creativecommons.org/licenses/by/4.0/.

(C) The Author(s) 2020 